\title{
Seafood insecurity, bush meat consumption, and public health emergency in West Africa: Did we miss the early warning signs of an Ebola epidemic?
}

\author{
Ahmed S Khan ${ }^{1 *}$ and Sanie SS Sesay ${ }^{2}$
}

\footnotetext{
* Correspondence:

ahmed.khan@smu.ca

${ }^{1}$ School of Business | School of Environment, Saint Mary's

University, Halifax, NS, Canada Full list of author information is available at the end of the article
}

\begin{abstract}
In this article, we frame issues around food security and the Ebola epidemic in West Africa and discuss the potential contribution of interrelated factors like seafood access, bush meat consumption, and public health concerns with the recent outbreak. Since seafood is a major dietary constituent in the affected countries, we posit that seafood unavailability due to unsustainable fishing practices and global change may increase the demand for bush meat and the risk of exposure to zoonosis such as Ebola through hunting and wildlife interactions. We discuss the potential contribution of these contextual drivers to public health within the wider milieu of changing climate, habitat disruptions, human migration and its implication for adaptive capacity, resilience and environmental governance. We conclude with policy options and research directives in addressing regional food security challenges, maritime policy, and emerging global health concerns.
\end{abstract}

Keywords: Fisheries; Seafood security; Ebola; Wildlife interactions; Public health; Environmental governance; West Africa

\section{Springer}

\section{What has seafood got to do with Ebola?}

Since the outbreak of the Ebola epidemic in West Africa almost a year ago, little effort has been directed to understanding the contextual factors and drivers of its emergence and propagation, and how best to address the current crisis and prevent future ones. Most efforts and interventions have been targeted mainly at public health control measures with little attention to the link with food security, regional ecosystem dynamics, and global change. Moreover, this region is comprised of several fragile states and one of the most vulnerable in terms of food security and well-being (Jalloh et al. 2013; Khan and Sei 2015). Seafood is a major part of the diet in the sub-region (Smith et al. 2010), amounting to $70 \%$ of animal protein intake in coastal countries like Sierra Leone (FAO 2014). The small-scale sector plays a key and important role in this as it strives to address not only food security and well-being but also broader development issues (Neiland and Bene 2004; Kawarazuka 2010; Chuenpagdee 2011). Even with increases in catch landings, the sub-region has been witnessing a net fishery deficit with emphasis on both high-value exports for consumption and low-value for fish meal

(C) 2015 Khan and Sesay; licensee Springer. This is an Open Access article distributed under the terms of the Creative Commons Attribution License (http://creativecommons.org/licenses/by/4.0), which permits unrestricted use, distribution, and reproduction in any medium, provided the original work is properly credited. 
(Alder et al. 2008; Nunoo et al. 2009). With changing climate and macroeconomic policies that favor exports over local consumption (Kaczynski and Fluharty 2002; Alder and Sumaila 2004; Lam et al. 2012), there has being an increase in bush meat hunting since the mid-1970s to the 1990s as shown in Figure 1 (Ntiamoa-Baidu 1997; Brashares et al. 2004; 2011). This trend has continued as the bush meat trade, estimated in billions of dollars, is a major dietary contributor in West Africa and a lucrative livelihood activity in many parts of the world (Bennett et al. 2007; Golden et al. 2011). The term bush meat (or wild game) is used in contrasts to local animal husbandry or livestocks. Thus in many coastal countries in West Africa, decreasing fish stocks indicate increasing demand for bush meat as an alternative source of animal protein and thus increased potential exposure to zoonosis like Ebola that are found in tropical rain forest ecosystems. Indeed, if fruit bats are potential reservoirs of Ebola and other mammalian species are end hosts (Leroy et al. 2005; Groseth et al. 2007; Barrette et al. 2009), then monitoring bush meat trade and wildlife interactions could potentially reduce the risk of contagion. Conversely, sustainable fishing practices that pay attention to local food security needs will reduce the risk of contact to zoonosis (i.e. hotspots for infectious disease) such as Ebola virus.

The current epidemic is the worst in human history, about 12, 386 laboratory confirmed cases and about 7,573 deaths as of December $24^{\text {th }} 2014^{\mathrm{i}}$. This is expected to increase in the absence of better intervention strategies (WHO Ebola Response Team 2014). The reaction to this epidemic has been a situation of too little too late, with some medical resources and international commitment only beginning to ensue after the epidemic got out of control (Farrar and Piot 2014). This has resulted in a huge repercussion on all fabrics of social life: from lock downs to closures of public services such as schools and banks, to broader human development implications including food price surges, regional trade, and the global economy.

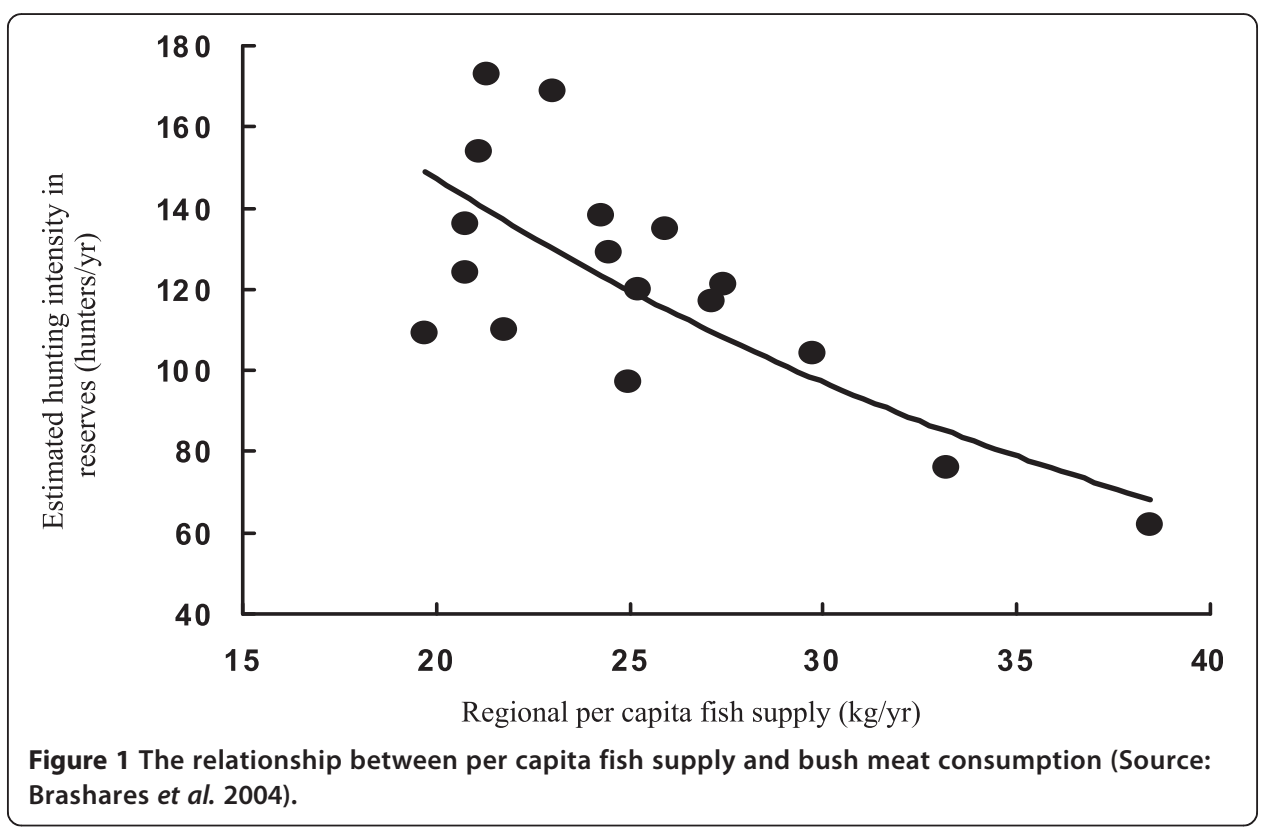


Although the international risk of contagion is low in the short term, there are ramifications if there are outbreaks in countries with direct flight connections to West Africa and Europe (Gomes et al. 2014). Hence countries that could potentially be affected are instituting travel restrictions and developing national public health action plans to deal with possible cases. In a concerted effort, humanitarian agencies and ministries of health in the affected countries are soliciting relief and medical supplies to halt the spread of the disease. Are these measures enough to curtail the current epidemic? So far, they don't seem to be working with the cases of Ebola escalating in the region and incidences in other non-neighboring countries. To understand how the current epidemic arose, we need to appreciate the multiple precipitating drivers and recognise that the epidemic is a symptom of much bigger problems stemming from sustainable development needs.

In this article, we first provide an overview of the disease, and its linkages with food security and wildlife management. Next, we argue for a holistic approach in curtailing the spread and preventing future epidemics recognizing the multiple pathways and inter-related factors starting with food and nutritional well-being, wildlife management, climate related changes, and crisis management. Finally, we delve into various governing options and conclude with areas for further research recognizing that protein dietary needs and environmental health are two of several determinants of human well-being.

\section{Genesis of the current epidemic in West Africa}

The Ebola virus can be traced to the Congo as far back as the mid-1970s when it first occurred in a river basin by the same name (WHO 1978; Groseth et al. 2007; Barrette et al. 2009). Prior to this epidemic in West Africa, previous outbreaks have been reported in countries such as the Congo, Gabon, Russia, Uganda, Italy, US, and the Philippines $^{\mathrm{ii}}$. Various species of fruit bat present in sub-Saharan Africa are thought to be reservoirs (Leroy et al. 2005), with apes and swine thought to be end hosts (Barrette et al. 2009; Groseth et al. 2007). Transmission to humans is thought to occur through contact with infected animal tissues and through bodily fluids (WHO Ebola Response Team 2014). Moreover, there is no proven or approved treatment, although drugs like ZMapp $^{\circ}$ and other experimental antiretroviral medications have all been used without robust clinical trial. This uncertainty frightens many public health authorities and poses communication challenges to local communities grappling with the epidemic. Like with many other viral haemorrhage fevers (VHFs), there are proven public health control measures like prompt diagnosis and isolation of cases, quarantine of potential cases, surveillance of high risk contacts, safe burial of deceased patients, social distancing and travel restrictions and screening (Feldmann and Geisbert 2011; WHO Ebola Response Team 2014).

There are a number of factors responsible for this epidemic and its rate of progression. First, these countries have not dealt with Ebola before and this led to a lot of initial confusion about the nature of the virus and its transmission. Without the benefit of accurate and prompt diagnosis, it was difficult to differentiate Ebola from other more common locally endemic conditions like malaria and Lassa fever. Second, the international community was slow in recognizing that the epidemic was "a public health emergency of international concern" and to respond and augment adequate resources in the affected countries (WHO Ebola Response Team 2014). Third, the lack of proven 
curative treatment, with only experimental therapy and untested vaccines that are controversial thwarts immediate intervention. Furthermore, past incidences of side effects and deaths from trial drugs in the sub-region have led to public mistrust and legal claims (Jegede 2007; Lenzer 2011). Fourth, due to the geography of the region, with many populous towns in the Mano River basin bordering Guinea, Liberia and Sierra Leone, cross-border travel increases the risk of contagion from rural to urban areas in the shortest possible time. Finally, this epidemic is a symptom of a much bigger problem: fragile states including Sierra Leone and Liberia with ailing healthcare systems and inadequate health infrastructure. For instance, the doctor to patio ratio in 2010 measured as a density of physicians per 1,000 people is relatively lower in Sierra Leone (0.022) compared to Nigeria (0.408), a non-fragile state ${ }^{\mathrm{iii}}$.

Could we have predicted such epidemics before they occur? We posit that yes, the warning signs were evident. Escalating food prices and declining trend in local food production and low household incomes point to a vulnerable situation (Jalloh et al. 2013). Knowing that Ebola is not the only VHF in the affected region sends heightened signals for public health preparation and action plans (Schoepp et al. 2014). Just two years ago, there was a large epidemic of Cholera in the same region with cross-border spread hinting at the fragile nature of the public healthcare systems. A successful approach to such epidemics should include a synergistic approach between nutritional well-being, public health and environmental governance. Thus, the need to understand the complex and interlinked relationships between seafood and wildlife interactions prompts us to explore response strategies that go beyond sectoral health policies.

\section{Interplay between seafood security, wildlife management and public health}

The prevalence of hunger and malnutrition in Sub Saharan Africa has been ranked as "serious" and "alarming", and has implications for infant mortality rate and life expectancy (wheeler and von Braun 2013). Although population increase is often seen as a concern for food security (Jalloh et al. 2013), climate change is increasing becoming another threat to reckoned with. Changing climate in the past few decades have consequences on both terrestrial and seafood production systems (Lam et al. 2012; Katikiro and Macusi 2012; Jalloh et al. 2013). Climate variability has consequences for seafood availability and large marine ecosystem dynamics bordering the affected countries (HardmanMountford and McGlade 2003; Lam et al. 2012). It has been demonstrated that food consumption patterns change with the availability and access of seafood for other protein substitutes such as bush meat. For instance, seafood unavailability has been linked to an increase in wildlife hunters as well as bush meat supply in local markets (Brashares et al. 2004). Recognizing that there is a stronger interactivity between the two protein-based food systems, this has implications for public health through potential contagion with wildlife (Bennett 2002; Rao and McGowan 2002; WHO 2003).

Similarly, climate change has potential impacts on the life cycle of pathogens that affects food production systems and human well-being (Daszak et al. 2000; McMichael et al. 2006; Groseth et al. 2007). Climate-related migrations of pathogens through reservoir hosts and vectors due to habitat disruptions, urbanization, and human migrations are emerging public health concerns (Hale et al. 2000; McMichael et al. 2003). In Western Africa where wildlife populations are historically and increasingly being part 
of local food systems and economic opportunities (Ntiamoa-Baidu 1997; Brashares et al. 2004), incidence of zoonosis creates high vulnerability to household food security and public health (Kawarazuka 2010; Wheeler and von Braun 2013; Schoepp et al. 2014).

What is discouraging is that most research on the impact of global change on local food systems and infectious diseases look at single causal factors without addressing the multiple pathways, complex interactions, and contextual relationships (Patz et al. 2000; Xun et al. 2010). Despite the body of evidence towards climate variability and pest and diseases and food systems (McMichael et al. 2006), predicting the many causal pathways and trends is challenging due to issues around attributing and contributing factors. Unravelling these multiple factors and their interactions with livelihoods, institutional structures, and decision-making processes could contribute to a better understanding of early warnings, response strategies, and post-crisis management (Dudley 2004; Altizer et al. 2013). Reactive strategies targeted at preventing such epidemics are likely to be inadequate without elucidating on these complex nature-society interactions (Figure 2).

Knowing that food security has been a long term issue in the sub-region, the question becomes how can policy makers improve the adaptive capacity to recover and cope in the short-term as well as being resilient to shocks in the long-term? A healthy community in times of crisis requires an adaptation strategy from being 'vulnerable' to 'resilient' and from 'dis-ease' to 'ease' (Almedom and Tumwine 2008). It has been suggested that a combination of tools and approaches that draw on food studies, epidemiology, and environment governance is necessary in dealing with multiple entry points and feedbacks (Fraser et al. 2003; McMichael et al. 2006, Armitage and Plummer 2010). Whilst some researchers have argued for a socio-ecological and resilience approach to pandemics (Cumming 2010), others have underscored nutritional well-being and food

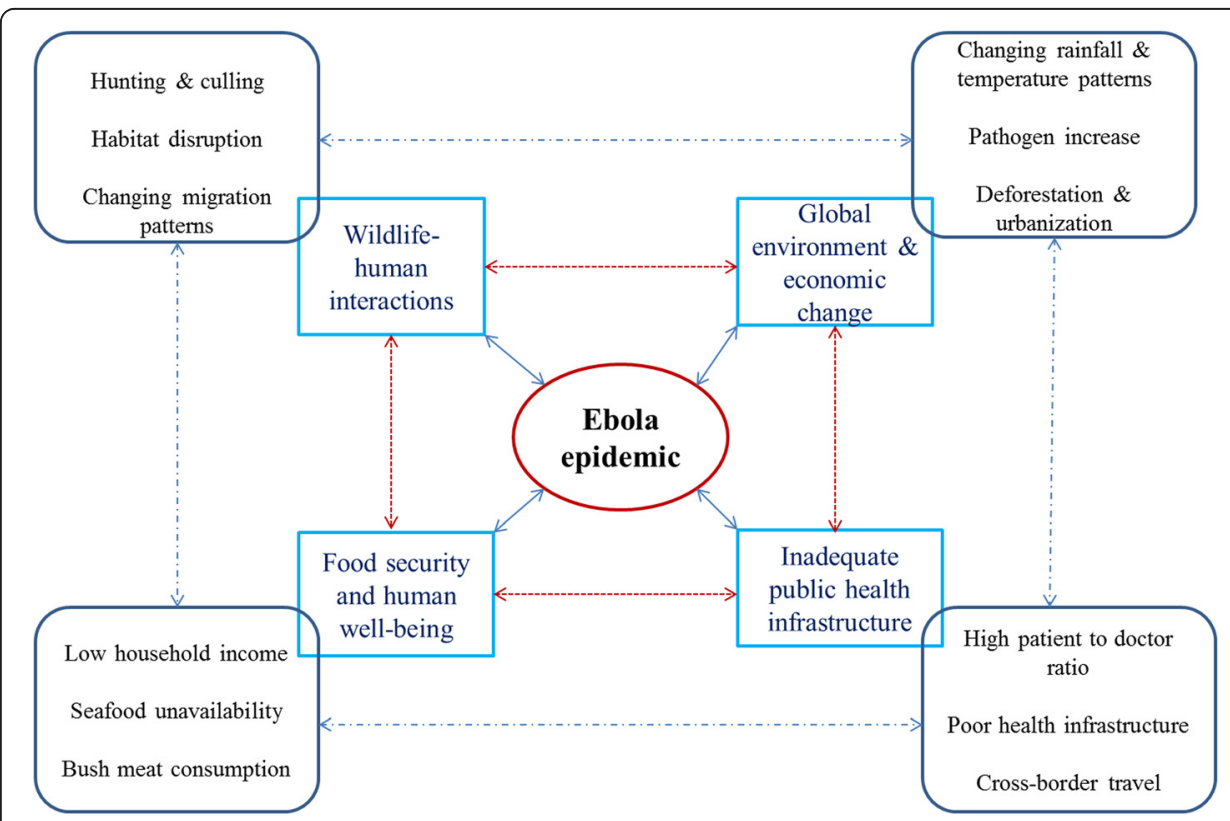

Figure 2 Conceptual linkages in human-nature interactions across marine and terrestrial systems for food security and the implication for Ebola and global public health. 
secured households (Kawarazuka 2010; Coulthard 2012). In other words, "building resilience requires changes in behaviours and norms, transmitted through social [and policy] networks" that fosters local food security (Frankenberger and Constas 2014: 744). Given this, making synergies through policy networks especially between environmental health and governance is imperative for social resilience that strengthens well-being (Fraser et al. 2003; Armitage et al. 2011; Broch 2013).

Xun et al. (2010) argues that scale presents a bigger challenge in the context of vulnerability assessment (spatial and temporal), as well as bio-complexity in terms of disease ecology and the dynamics in attaining sustainable development. These social interactions across scales and amongst multiple actors are better framed under the rubric of governance. Governance deals with both state and non-state institutions, rules of decision-making, in addition to scale matching (Armitage and Plummer 2010). It is a mechanism to address food security under uncertainties as well as ecosystem shifts. This is in recognition of the multiple drivers, pathways, and feedback loops necessary for adequately addressing the issues around food production and global change (Folke et al. 2005; Miller et al. 2010). This deserves more focus to which we now turn.

\section{Synergies between local food systems and environmental health}

Arguably, vulnerable populations that are food insecure and with an inadequate health care infrastructure signal potential crisis in the event of an epidemic such as EVD. Because EVD is a multi-faceted issue with several entry points, governance mechanisms are necessary for making linkages and synergies across sectors, jurisdictional scales, and interest groups. "Because much of the world's seafood comes from regions with weak governance, improved governance is essential to sustain or increase seafood's contribution to food security" (Smith et al. 2010: 785). Adapting to food or climate related disasters also have an institutional dimension in terms of decision support tools that are intricately connected to multi-level governance arrangements (Kooiman et al. 2005, Armitage and Plummer 2010). These arrangements provide opportunity for linking risk reduction measures in public health with capacity building efforts in promoting well-being (Hess et al. 2012).

There is a lot to learn from the history on governance in food related crisis and public health emergencies. In times of disasters, some scholars have argued that windows of opportunities for social change and transformation do emerge for institutional resilience (Scheffer et al. 2002; Folke et al. 2005; Birkmann et al. 2008). Extreme events have presented opportunities to adapt and cope through strengthening local institutions and training to help manage emerging risks. Previous efforts at curtailing the EVD in Uganda involved rigorous health protocols for isolation, surveillance, health care treatment, supported by local authorities with financial assistance by donor agencies (Borchert et al. 2011). The key lesson is to augment local capacity and resources and strengthen institutional infrastructure. In the case of addressing BSE outbreak in Canada, another zoonotic disease, various adaptation strategies were initiated, including post-crisis coping strategies, food production initiatives, and enhanced engagement with stakeholders (Anderson and McLachlan 2012).

Building local community resilience that focuses on response and recovery as well as national action plans that promote prevention and preparation is necessary (Keim 
2008). Exemplifying uncertainties due to climate change, inadequate knowledge, and other institutional constraints do provide the basis for adaptive management (Walters 1986; Nichols et al. 2011). Drawing on diverse disciplinary perspectives, curtailing the epidemic could entail both anticipatory risk reduction measures as well as crisis management through synergistic efforts in addressing food security and environmental health. Moreover, crisis management activities can be made complementary to the adaptive management cycle especially in planning, implementing, monitoring and evaluating action plans in resource management (Figure 3). The governing processes in these interventions could strengthen the science-policy divide; build partnerships, and engage stakeholders in collective action on food security and environmental health (Anderson and McLachlan 2012).

Several models for controlling disease and attaining nutritional well-being have been proposed in the African context (Kock et al. 2002). These include: i) a communitybased production system that is local and affordable and focuses on the principle of sufficiency, ii) partnership arrangements between governments and private sector organizations by sharing of benefits and cost and promoting health standards and sanitary research, and iii) a top-down and centralised government agency that promotes and fosters public health policy and the monitoring and surveillance of pathogens.

Other creative governance and flexible decision-making arrangements could be cost-effective for dealing with human well-being through benefit sharing schemes. The Novartis Coartem Anti-malarial Treatment program is an example on a cost recovery drug program spearheaded by industry in partnership with governments, multilaterals, and local partners. This was possible under the Convention on Biological Diversity and Nagoya Protocols on Access and Benefit Sharing arrangements (TEEB 2009). Also,

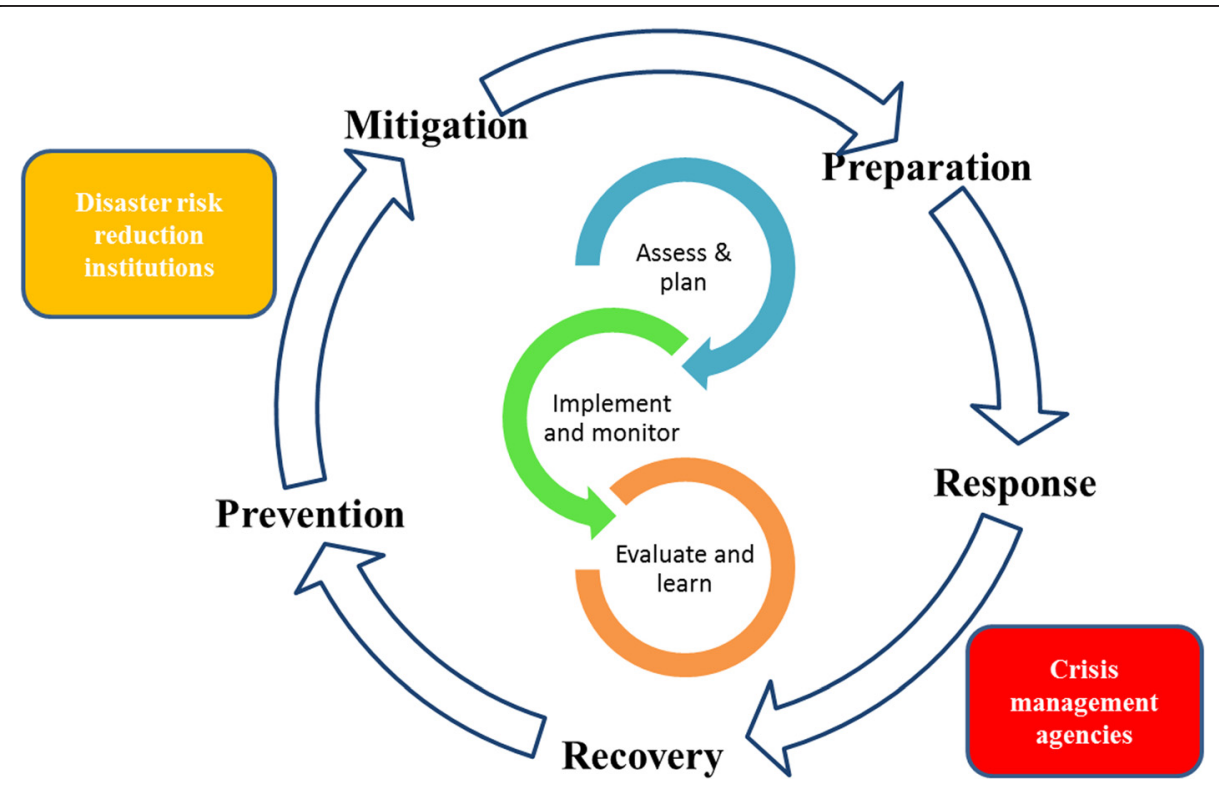

Figure 3 Integrating risk reduction and adaptive measures for food security needs and public health in the case of West Africa. The various colors denote cautionary traffic signals and the arrows denote the need to constantly adjust from disaster planning to post-crisis recovery. Adapted from Folke et al. (2005); Keim (2008); Hess et al. (2012). 
coordination efforts through regional nodes and risk mapping can be supportive in curtailing the epidemic (Cumming 2010; Semenza et al. 2012). Furthermore, a robust regional monitoring scheme is needed. One that entails international travel checks from affected areas due to high mobility of coastal fishers, cross-border land travels, and global airline networks (Tatem 2009; Binet et al. 2012; Gomes et al. 2014). This could build upon the legacy of the World Health Organization (WHO) for travel protocols such as the Yellow Card and the International Maritime Organization (IMO) on safety and health guidelines ${ }^{\text {iv }}$.

We suggest rather than putting emphases on reactive measures such as lock-downs and drug trials as short-term strategies alone, long-term multi-prong approaches that include food security considerations, risk mapping, and environmental monitoring is necessary (Dudley 2004; Frankenberger and Constas 2014). Improving bottom-up initiatives for community health and resilience (Berkes and Ross 2013; Hess et al. 2012) and taking into account broader regional governance and policy directives are crucial (Khan and Mikkola 2002).

Communicating scientific insights in a region with low literacy in European languages is a task that could benefit from inter-cultural and social learning. Besides, the diversity in beliefs, plethora of world views, and quaint cultural practices make effective communication even more of a priority (Fanon 1961; Rajnarayan 2002; Jegede 2007). Fortunately, this presents an opportunity to bridge science and policy through public engagement and social learning platforms amongst health care professionals, resource managers, policy makers and local community leaders (Kock et al. 2002; Dudley 2004; Hess et al. 2012; Dietz 2013).

Social and professional networks are also useful for knowledge mobilization and as bridging organizations for community resilience (Galaz 2009). This could take the form of institutional partnership and information sharing for public health decision making (Dudley 2004), remittances for hospital supplies or humanitarian relief, and through public sensitization campaigns (Hess et al. 2012). Volunteer work through the likes of Doctors without Borders (MSF) and Doctors in the Diaspora could augment local support on the ground. These collective support systems garnered through various networks could be crucial at the local level where resources are limited.

Because the vulnerability of the food systems in the sub-region will affect public health policies and environmental governance, we strongly posit that multiple pathways and entry points present opportunities for various stakeholders to self-organize in addressing the issues either by reducing vulnerability or building resilience.

\section{Way forward}

Coastal fisheries and seafood contributes tremendously to the nutritional well-being of the affected Ebola countries in West Africa. In the immediate absence of vaccines and not knowing whether bush meat and livestocks are tainted (Groseth et al. 2007), seafood is currently providing the necessary caloric intake, essential fatty acids, and micro-nutrients for bolstering the immune systems for those affected to be resilient (Khan and Sei 2015). Similarly for the healthy, seafood is the main nutritional protein available to be resistant to the disease. The current epidemic is a symptom of complex interplay of social, economic, political, and environmental factors that impact seafood security and changing dietary patterns with consequences on well-being and 
environmental health. This situation is exacerbated by high poverty levels and regional migration across borders both on land and at sea (Neiland and Bene 2004; Binet et al. 2012; Gomes et al. 2014). As shown in Figure 2, there are many entry points and pathways in addressing the Ebola issue, including food security and well-being. Understanding how food policies especially sustainable seafood production in meeting local dietary needs benefit public health is central in identifying multiple policy windows for crisis management and future prevention of zoonosis (WHO 2003; Brashares et al. 2004; Guernier et al. 2004; Barrette et al. 2009).

In the long-term, creating early warning networks, monitoring environmental health, and strengthening local and national food security institutions in promoting adaptive capacity is critical. Attaining collective action through cross-border collaboration, institutional partnerships, and creative governing arrangements at the regional and international level is also important. Knowing the importance of seafood to nutritional well-being and long-term food security in the region, integrating health research with environmental management and regional economic development is also imperative as emerging pathogens are often linked to local and global drivers (Dudley 2004; Daszak et al. 2000; Barrette et al. 2009). With the International Maritime Organization policy on EVD, vessels exporting seafood from the sub-region are sometimes quarantined for 21 days, thus affecting product quality, fish prices, and regional trade. Equally important is creating institutional synergy and cross-sectoral policies between maritime seafood production and terrestrial wildlife management for avoiding potential environmental risks (Leroy et al. 2005; Richter and Cumming 2006; Galaz 2009).

Dietary seafood intake and environmental health are two of many determinants of well-being and community resilience (Kawarazuka 2010). Recognizing that Ebola is a public health emergency of global proportion, regional working groups and task force on food security and ecosystems spearheaded by UN agencies could provide policy inputs on short and long-term proactive measures. There are many lessons to share with other regions on food security and wildlife interactions, not only for avoiding pandemics, but for innovative institutional mechanisms for addressing future crisis. We may have missed the early warning signs of a catastrophe by ignoring the contribution of food and well-being to public and environmental health, but there is no reason why we cannot curtail this epidemic and prevent future occurrences.

\section{Endnotes}

${ }^{i}$ CDC. 2014. Case counts. http://www.cdc.gov/vhf/ebola/outbreaks/2014-west-africa/ index.html.

ii CDC. 2014. Outbreak Chronology: Ebola Virus Disease. Accessed Sept. $30^{\text {th }}$ 2014: http://www.cdc.gov/vhf/ebola/outbreaks/history/chronology.html.

iii Doctor to Patient Ratio in Africa in 2006. Accessed Oct $20^{\text {th }} 2014$ : http://apps.who. int/gho/data/node.main.A1444.

iv $I M O$ Circular Letter No. $348510^{\text {th }}$ September - Full and effective implementation of maritime security measures to assist in preventing the spread of EVD. http://www. imo.org/MediaCentre/HotTopics/ebola/Documents/3485.pdf. 
Author's contributions

Both authors read and approved the final manuscript.

\section{Authors informations}

ASK is an interdisciplinary scholar in human-nature interactions especially in fisheries and seafood trade, global change, and institutional governance. He obtained his PhD at Memorial University and spent a year and half with UNEP-IEMP as a Research Fellow. As part of his portfolios, he assessed ecosystem service synergies under changing climate in the upper Nile basin in Eastern Africa and adaptation planning on Small Islands Developing States in South Eastern Africa. Prior to that, he did his MSc at the University of British Columbia and earlier on served as a United Nations Volunteer in The Gambia. His work has been featured in the journals Ambio, Coastal Management, Fisheries Research, Marine Policy, Regional Environmental Change, and Science. He is currently a Postdoctoral Research Fellow at Saint Mary's University, Halifax, NS, Canada.

SSSS is a general physician (MD) and clinical epidemiologist (PhD). He worked with the Government Health Service in Sierra Leone for four years as general physician, including two years at the Lassa Fever Isolation Unit in Kenema. He later joined the Medical Research Council (UK) in The Gambia for about six years; where he worked in the fields of clinical trials and malaria epidemiology. He relocated to Malawi for his Malaria Capacity Development Consortium (MCDC) funded PhD fellowship, which he completed in 2014. The MCDC is funded by the Wellcome Trust (Grant number WT084289MA). He has published in journals such as PloS One, the Lancet, Malaria Journal, and Emerging Infectious Disease. He is currently a postdoctoral researcher at Department of Clinical Sciences of the Liverpool School of Tropical Medicine, UK.

\section{Acknowledgements}

We are grateful to colleagues who directed us to relevant materials in making connections between seafood, public health and environmental governance especially Professor Firkes Berkes, Dr. Sia Kpakiwa, Dr. Tara Whitty and Dr. John Abraham. Editorial suggestions by Ms. Tiffanie Rainville and Karen Mrema on an earlier manuscript are highly appreciated. We thank Professor Justin Brashares for Fig 1, with reprint permission granted by AAAS. This collaborative piece is dedicated to the memory of Dr. Humar S. Khan aka Squazo, who inspires us to be selfless. Ahmed S. Khan acknowledges financial support during his postdoctoral fellowship from Saint Mary's University, the Social Sciences and Humanities Research Council of Canada and the Natural Sciences and Engineering Research Council of Canada. Sanie S.S. Sesay is supported through the Malaria Capacity Development Consortium funded by the Wellcome Trust.

\section{Author details}

${ }^{1}$ School of Business | School of Environment, Saint Mary's University, Halifax, NS, Canada. ${ }^{2}$ Department of Clinical Sciences, Liverpool School of Tropical Medicine, Pembroke Place, Liverpool, UK.

Received: 24 October 2014 Accepted: 5 January 2015

Published online: 11 March 2015

\section{References}

Alder, J, and UR Sumaila. 2004. Western Africa: a fish basket of Europe past and present. Journal of Environment and Development 13: 156-178.

Alder, J, B Campbell, V Karpouzi, K Kaschner, and D Pauly. 2008. Forage fish: from ecosystems to markets. Annua Review of Environment and Resources 33: 153-166.

Almedom, AM, and JK Tumwine. 2008. Resilience to disasters: a paradigm shift from vulnerability to strength. African Health Sciences (SI on Resilience) 8S: 1-4.

Altizer, S, RS Ostfeld, PTJ Johnson, S Kutz, and CD Harvell. 2013. Climate change and infectious disease: from evidence to a predictive framework. Science 341: 514-519

Anderson, CR, and SM McLachlan. 2012. Exiting, enduring and innovating: farm household adaptation to global zoonotic disease. Global Environmental Change 22: 82-93.

Armitage, D, and R Plummer (eds.). 2010. Adaptive capacity and environmental governance. Berlin: Springer.

Armitage, D, C Bene, AT Charles, D Johnson, and EH Allison. 2011. The interplay of well-being and resilience in applying a social-ecological perspective. Ecology and Society 17: 15

Barrette, RW, SA Metwally, JM Rowland, L Xu, SR Zaki, ST Nichol, PE Rollin, JS Towner, W-J Shieh, B Batten, TK Sealy, C Carrillo, KE Moran, AJ Bracht, GA Mayr, M Sirios-Cruz, DP Catbagan, EA Lautner, TG Ksiazek, WR White, and MT McIntosh. 2009. Discovery of swine as a host for the Reston ebolavirus. Science 325: 204-206.

Bennett, EL. 2002. Is there a link between wild meat and food security? Conservation Biology 16: 590-592.

Bennett, EL, E Blencowe, K Brandon, D Brown, RW Burn, G Cowlishaw, G Davies, H Dublin, JE Fa, EJ Milner-Gulland, JG Robinson, JM Rowcliffe, FM Underwood, and DS Wilkie. 2007. Hunting for consensus: reconciling bush meat harvest, conservation, and development policy in West Central africa. Conservation Biology 21: 884-887.

Berkes, F, and H Ross. 2013. Community resilience: towards an integrated approach. Society and Natural Resource 26: $5-20$

Binet, T, P Failler, and A Thorpe. 2012. Migration of Senegalese fishers: a case for regional approach to management. Maritime Studies 11: 1

Birkmann, J, P Buckle, J Jaeger, M Pelling, N Setiadi, M Garschagen, N Fernando, and J Kropp. 2008. Extreme events and disasters: a window of opportunity for change? Analysis of organizational, institutional and political changes, formal and informal responses after mega-disasters. Natural Hazards 55: 637-655.

Borchert, M, I Mutyaba, M Van Kerkhove, J Lutwama, H Luwaga, G Bisoborwa, J Turyagaruka, P Pirard, N Ndayimirije, P Roddy, and P Van Der Stuyft. 2011. Ebola haemorrhagic fever outbreak in Masindi District, Uganda: outbreak description and lessons learned. JBMC Infectious Diseases 11: 357.

Brashares, JS, P Arcese, MK Sam, PB Coppolillo, ARE Sinclair, and A Balmford. 2004. Bush meat hunting, wildlife declines, and fish supply in West Africa. Science 306: 1180-1183. 
Brashares, JS, CD Golden, KZ Weinbaum, CB Barrett, and GV Okello. 2011. Economic and geographic drivers of wildlife consumption in rural Africa. PNAS 108: 13931-13936.

Broch, HB. 2013. Social resilience - local responses to changes in social and natural environments. Maritime Studies 12: 6. Chuenpagdee, R (ed.). 2011. World small-scale fisheries contemporary visions. Delft: Eburon.

Coulthard, S. 2012. Can we be both resilient and well, and what choices do people have? Incorporating agency into the resilience debate from a fisheries perspective. Ecology and Society 17(1): 4

Cumming, GS. 2010. Risk mapping for avian influenza: a social-ecological problem. Ecology and Society 15: 32.

Daszak, P, AA Cunningham, and AD Hyatt. 2000. Emerging infectious diseases of wildlife- threats to biodiversity and human health. Science 287: 443-449.

Dietz, T. 2013. Bringing values and deliberations to science communication. PNAS 110: 14081-14087.

Dudley, JP. 2004. Global zoonotic disease surveillance: an emerging public health and biosecurity imperative. BioScience 54: 982-983.

Fanon, F. 1961. The wretched of the earth. New York: Groove Press

FAO. 2014. The state of world fisheries and aquaculture 2013. Challenges and opportunities. Rome: FAO.

Farrar, JJ, and P Piot. 2014. The Ebola emergency - immediate action, ongoing strategy. New England Journal of Medicine Doi:10.1056/NEJMe1411471.

Feldmann, H, and TW Geisbert. 2011. Ebola haemorrhagic fever. Lancet 377: 849-862.

Folke, C, T Hahn, P Olsson, and J Norberg. 2005. Adaptive governance of social-ecological systems. Annual Review of Environment and Resources 30: 441-473.

Frankenberger, TR, and MA Constas. 2014. IFPRI 2020 conference: building resilience for food and nutritional security, Addis Ababa, 15-17 of May 2014: a synthesis. Food Security 6: 743-745.

Fraser, EDG, W Mabee, and O Slaymaker. 2003. Mutual vulnerability, mutual dependence: the reflexive relation between human society and the environment. Global Environmental Change 13: 137-144.

Galaz, V. 2009. Pandemic 2.0: Can information technology help save the planet? Environment 5: 20-28.

Golden, DC, C Lia, H Fernald, JS Brashares, BJR Rasolofoniaina, and C Kremen. 2011. Benefits of wildlife consumption to child nutrition in a biodiversity hotspot. PNAS 49: 19653-19656.

Gomes, MFC, A Pastore y Piontti, L Rossi, D Chao, I Longini, ME Halloran, and A Vespignani. 2014. Assessing the international spreading risk associated with the 2014 West African Ebola outbreak. PLOS Currents Outbreaks. Doi:10.1371/currents. outbreaks.cd818f63d40e24aef769dda7df9e0da5

Groseth, A, H Feldmann, and JE Strong. 2007. The ecology of Ebola virus. Trends in Microbiology 15(9): 408-416.

Guernier, V, ME Hochberg, and J-F Guégan. 2004. Ecology drives the worldwide distribution of human diseases. PLoS Biology 2(6): e141.

Hale, S, S Kovats, and A Woodward. 2000. What El Nino can't tell us about human health and global climate change? Global Change Human Health 1: 66-77.

Hardman-Mountford, NJ, and JM McGlade. 2003. Seasonal and inter-annual variability of oceanographic processes in the Gulf of Guinea: an investigation using AVHRR sea surface temperature data. International Journal of Remote Sensing 24(16): 3247-3268.

Hess, JJ, JZ McDowell, and G Luber. 2012. Integrating climate change adaptation into public health practice: using adaptive management to increase adaptive capacity and build resilience. Environmental Health Perspectives 120: $171-179$.

Jalloh, A, GC Nelson, TS Thomas, R Zougmore, and H Roy-Macauley (eds.). 2013. West African agriculture and climate change: a comprehensive analysis. Washington, DC: International Food Policy Research Institute.

Jegede, AS. 2007. What led to the Nigerian boycott of the polio vaccination campaign? PLOS Medicine 4(3): e73. doi: 10.1371/journal.pmed.0040073.

Kaczynski, V, and DL Fluharty. 2002. European policies in West Africa: Who benefits from fisheries agreements? Marine Policy 26: 75-93.

Katikiro, RE, and ED Macusi. 2012. Impacts of climate change on West African fisheries and its implications on food production. Journal of Environmental Science and management 15: 83-95.

Kawarazuka, N. 2010. The contribution of fish intake, aquaculture, and small-scale fisheries to improving nutrition: a literature review. The WorldFish center working paper No.2106. Penang, Malaysia: The WorldFish Center.

Keim, ME. 2008. Building human resilience: the role of public health preparedness and response to as an adaptation to climate change. American Journal of Preventive Medicine 35: 508-516.

Khan, AS, and H Mikkola. 2002. Sustainable ocean development: an initiative for the management and protection of the marine and coastal resources of the Economic Community of West Africa States (ECOWAS) Sub region. UNIGAM 0001, Banjul: University of the Gambia.

Khan, AS, and S Sei. 2015. The co-governance of fisheries in post-conflict Sierra Leone: Is the transition for better or for worse? In In Interactive Governance for Small-scale Fisheries: Global Reflections, eds. S Jentoft, R Chuenpagdee. MARE Publication Series. Amsterdam: Springer [Forthcoming].

Kooiman, J, M Bavinck, S Jentoft, and R Pullin (eds.). 2005. Fish for life: interactive governance for fisheries. Amsterdam: Amsterdam University Press.

Kock, R, B Kebkiba, R Heinomen, and B Bedane. 2002. Wildlife and pastoral society - shifting paradigms in disease control. Annals New York Academy of Sciences 969: 24-33.

Lam, WY, WWL Cheung, W Swartz, and UR Sumaila. 2012. Climate change impacts on fisheries in West Africa: Implications for economic, food and nutritional security. African Journal of Marine Science 34: 103-117.

Lenzer, J. 2011. Pfizer settles with victims of Nigerian drug trial. British Medical Journal 343: d5268. doi: 10.1136/bmj.d5268.

Leroy, EM, B Kumulungu, X Pourrut, P Rouquet, A Hassanin, P Yaba, A Delicat, JT Paweska, J-P Gonzalez, and R Swanepoel. 2005. Fruit bats as reservoirs of Ebola virus. Nature 438: 575-576.

McMichael, AJ, D Campbell-Lendrum, K Ebi, A Githeko, J Scheraga, and A Woodward (eds.). 2003. Climate change and human health: risks and responses. Geneva: WHO.

McMichael, AJ, RE Woodruff, and S Hales. 2006. Climate change and human health: present and future risks. The Lancelet 367: 859-869. 
Miller, K, A Charles, M Barange, K Brander, V Gallucci, MA Gasalla, AS Khan, G Munro, R Murtugudde, RE Ommer, and PI Perry. 2010. Climate change, uncertainty, and resilient fisheries: Institutional responses through integrative science. Progress in Oceanography 87(1-4): 338-346

Neiland, AR, and CE Bene (eds.). 2004. Poverty and small-scale fisheries in West Africa. New York: Springer.

Nichols, JD, MD Koneff, PJ Heglund, MG Knutson, ME Seamans, JM Morton, MT Jones, GS Boomer, and BK Williams. 2011. Climate change, uncertainty, and natural resource management. Journal of Wildlife Management 75: 6-18.

Ntiamoa-Baidu, Y. 1997. Wildlife and food security in Africa. Rome: FAO Conservation Guide No. 33. FAO.

Nunoo, FKE, JO Boateng, AM Ahulu, KA Agyekum, and UR Sumaila. 2009. When trash fish is treasure: the case of Ghana in West Africa. Fisheries Research 96: 167-172.

Patz, JA, TK Graczyk, N Geller, and AY Vittor. 2000. Effects of environment change on emerging parasitic diseases. International Journal of Parasitology 30: 1395-1405.

Rajnayaran, C. 2002. Plague panic and epidemic politics in India, 1896-1914. Epidemics and Ideas: Essays on the Historical Perception of Pestilence (1992). In The origins of industrial capitalism in India: business strategies and the working classes in Bombay, 1900-1940, vol. 51. Cambridge: Cambridge University Press.

Rao, M, and PJK McGowan. 2002. Wild meat use, food security, livelihoods, and conservation. Conservation Biology 16: 580-583.

Richter, HV and GS Cumming. 2006. Food availability and the annual migration of the straw coloured fruit bat (Eidolon helvum) at Kasanka National Park, Zambia. Journal of Zoology, London 268: 35-44.

Scheffer, M, F Westley, WA Brock, and M Holmgren. 2002. Dynamic interaction of societies and ecosystems - linking theories from ecology, economy and sociology. In Panarchy: understanding transformations in human and natural systems, ed. LH Gunderson and CS Holling, 195-240. London: Island Press.

Schoepp, RJ, CA Rossi, SH Khan, A Goba, and JN Fair. 2014. Undiagnosed acute viral febrile illnesses, Sierra Leone. Emerging Infectious Disease 20: 1176-1182.

Semenza, JC, JE Suk, V Estevez, KL Ebi, and E Lindgren. 2012. Mapping climate change vulnerabilities to infectious diseases in Europe. Environmental Health Perspective 120: 385-392.

Smith, MD, CA Roheim, LB Crowder, BS Halpern, M Turnipseed, JL Anderson, F Acshe, L Bourillon, AG Guttormsen, AS Khan, LA Liguori, A McNevin, MI O'Connor, D Squires, P Tyedmers, C Brownstein, K Carden, DH Klinger, R Sagarin, and K Selkoe. 2010. Sustainability and global seafood. Science 327: 784-786.

Tatem, AJ. 2009. The worldwide airline network and the dispersal of exotic species: 2007-2010. Ecography 32: 94-102.

TEEB. 2009. 2009. The economics of ecosystems and biodiversity for business report. Geneva and Nairobi: UNEP.

Walters, CJ. 1986. Adaptive Management of Renewable Resources. New York: McGraw Hill.

Wheeler, T, and J von Braun. 2013. Climate change impacts on global food security. Science 341: 508-513.

WHO. 1978. Ebola hemorrhagic fever in Zaire, 1976. Report of an International Convention. Bulletin of the World Health Organization 56(2): 271-293.

WHO. 2003. Climate change and human health: risk and responses. Geneva: WHO in collaboration with UNEP and WMO.

WHO Ebola Response Team. 2014. Ebola Virus Disease in West Africa. The first 9 months of the epidemic and forward projections. New England Journal of Medicine Doi:10.1056/NEJMoa1411100

Xun, WW, AE Khan, E Michael, and P Vineis. 2010. Climate change epidemiology: methodological challenges. International Journal of Public Health 55: 85-96.

\section{Submit your manuscript to a SpringerOpen ${ }^{\circ}$ journal and benefit from:}

- Convenient online submission

- Rigorous peer review

- Immediate publication on acceptance

- Open access: articles freely available online

- High visibility within the field

- Retaining the copyright to your article 